\title{
Studying antioxidant, anti-inflammatory activities and antimicrobial of Iron nanoparticles biosynthesized from water extract of Mentha pulegium $L$
}

\author{
Sundus hameed Ahmed \\ Biological Department/ College of Science/ University of Al- Mustansyiriha \\ drsundusahmed@gmail.com
}

\begin{abstract}
:
Biosynthesis of Iron nanoparticles from Mentha pulegium $L$ by simple method by using water extract of Mentha pulegium L. The iron nanoparticles characterized by UV-visible spectroscopy, (FTIR) Fourier transform infrared spectroscopy, XRD and Scanning electron microscopy (SEM). The biological activity evaluation by anti-inflammatory and anti oxidant using evaluated in vitro 2,2-diphenyl-1- picrylhydrazyl (DPPH) assay, ABTS radical scavenging assay assay Iron chelating activity assay. The results also revealed that the water extract of Mentha pulegium $L$ and its iron nanoparticles represented the most potent in vitro antioxidant effect. Iron nanoparticles inhibited the growth of bacterial and fungal, these results suggested that iron nano particle could be an interesting to control pathogenic micro organisms.
\end{abstract}

Keywords: Iron nanoparticles, plant extracts, Mentha pulegium L, antioxidant activity, antiinflammatory activity.

\section{Introduction:}

Now a days great efforts were made to use green and environmentally friendly methods for synthesis nano materials, these efforts involve the use of plant or fruit extracts as detergent $(1,2)$. Metal ions reduce by plant extracts in a shorter time in compared with microbes, depending upon plant type and concentration of phytochemicals(3). Nanoparticles are synthesized within a few minutes or hours, whereas microorganism-based methods require a longer time $(4,5)$. Our work describes a green and rapid method using Mentha leaves, water extract solution for the biosynthesis of iron oxide nanoparticles without any additives protecting nanoparticles from aggregating. The current green method using rapid precursors of Mentha leaves extract provides high-yield nano materials with a good optical properties, and the method can be used to prepare nano oxides of other interesting materials. The $\mathrm{Fe}_{3} \mathrm{O}_{4}$ - 
NPs were prepared by using ferric sulfate as iron precursor and Mentha leaves extract as reducing agent and stabilizer.

\section{Materials and Methods}

$\mathrm{Fe}_{3} \mathrm{O}_{4}$-NPs were synthesized using the leaves extract of Mentha. Five gram powdered sample from Mentha pulegium $L$ extracted with $150 \mathrm{ml} \mathrm{D}$. W at room temperature. $0.1 \mathrm{M} \mathrm{FeSO}_{4}(40$ $\mathrm{ml}$ ) of water extract was added to $40 \mathrm{ml}$ leaves extract drop wise with continuous still changing the color of solution from pale yallow to black. The solution was centrifuged at $10,000 \mathrm{rpm}$, at $4^{\circ} \mathrm{C}$ for $15 \mathrm{~min}$ and pellet was dissolved in distilled water for periodic probe sonication for $5 \mathrm{~min}$ at $30 \pm 0.5^{\circ} \mathrm{C}$. Nano suspension thus obtained was dried in oven.

\section{Characterization of Iron Nanoparticle}

The structure and purity of $\mathrm{Fe}_{3} \mathrm{O}_{4}$-NPs identified by X-ray diffraction measurement. Recorded in the range 500-4000 $\mathrm{nm}$. UV-Vis spectral analysis was done by using UV-Vis, at the range of $200-600 \mathrm{~nm}$ and observed the absorption peaks at $\mathrm{nm}$ regions due to the excitation of surface Plasmon vibrations in the $\mathrm{Fe}_{3} \mathrm{O}_{4}$-NPs solution, which are identical to the characteristics UV-visible spectrum of metallic Iron and it was recorded. Scanning Electron Microscope (SEM) to characterize mean particle size and morphology of Iron oxide nanoparticles, SEM was performed using Schimadzu SEM machine of $20 \mathrm{KV}$ of accelerating voltage. FT-IR spectra of the $\mathrm{Fe}_{3} \mathrm{O}_{4}$-NPs were recorded in the range 500-4000 $\mathrm{nm}$ by (Shimadzu, Tokyo, Japan).

\section{DPPH radical scavenging assay:}

To $\mathrm{Fe}_{3} \mathrm{O}_{4}$-NPs solution of DPPH $(1 \mathrm{mM})$ an equal volume of the nano particle solution dissolved in water added at various concentrations from 100 to $750 \mu \mathrm{g} / \mathrm{ml}$ in a final volume of $1.0 \mathrm{ml}$. An equal amount of alcohol was added to the control. After $20 \mathrm{~min}$. absorbance was measured at $517 \mathrm{~nm}$. Experiment was performed in triplicate (6).

\section{ABTS radical scavenging assay:}

To the reaction mixture containing $0.3 \mathrm{ml}$ of ABTS radical, $1.7 \mathrm{ml}$ phosphate buffer and 0.5 $\mathrm{ml}$ Nano particle was added at various concentrations from 2 to $500 \mu \mathrm{g} / \mathrm{ml}$. Blank was carried out without drug. Absorbance was recorded at $734 \mathrm{~nm}$. Experiment was performed in triplicate (7). 


\section{Iron chelating activity assay:}

The chelation of ferrous ions by iron nanoparticles was estimated by method(8). Take $50 \mu 1$ of $\mathrm{FeCl}_{2}(2 \mathrm{mM})$ was added to $1 \mathrm{ml}$ of different concentrations of the extract $(0.2,0.4,0.8,1.6$ and $3.2 \mathrm{mg} / \mathrm{ml}$ ). The initiation of reaction by addition $(0.2) \mathrm{ml}$ of $5 \mathrm{mM}$ ferrozine solution. The mixture was vigorously shaken and left to stand at room temperature for $10 \mathrm{~min}$. The absorbance of the solution was thereafter measured at $562 \mathrm{~nm}$. The percentage inhibition of ferrozine-Fe $2+$ complex formation was calculated as $[(\mathrm{A} 0-\mathrm{As}) / \mathrm{As}] \times 100$, where A0 was the absorbance of the control, and As was the absorbance of the extract/ standard. Na2EDTA was used as positive control.

\section{Denaturation inhibition of albumin}

One persent $(1 \%)$ Human albumin was incubated at $37 \mathrm{C}^{\circ}$ for 20 minute, heated at $51^{\circ} \mathrm{C}$ cooling. Measured the turbidity at $660 \mathrm{~nm}$ by UV Visible Spectrophotometer. The Percentage of denaturation inhibition calculated by this equation $=($ Abs Control -Abs Sample) X 100/ Abs control.

\section{Detection membrane RBCs stabilization}

Human blood cells centrifuged by $3000 \mathrm{rpm}$ for $10 \mathrm{~min}$, precipitate washed with normal saline then suspended to $10 \% \mathrm{v} / \mathrm{v}$ by normal saline, suspension incubated at $56^{\circ} \mathrm{C}$ in water bath for $30 \mathrm{~min}$, centrifuged at $3000 \mathrm{rpm}$ for five minute detection the absorbance at $560 \mathrm{~nm}$. The Percentage of haemolysis inhibition calculated (9):

$\%$ inhibition $=($ Abs control - Abs sample $) X 100 /$ Abs control

\section{Microorganisms}

Culture of, Pseudomonas aeruginosa, Bacillus subtills, Escherichia coli, and Klebsiella pneumoneae species of bacteria and Aspergillus niger and Aspergillus flavus Candida spp. From puplic health center.

\section{Antibacterial activity}

The antibacterial activities of iron nanoparticle were carried out by disc diffusion method(9). Nutrient agar medium plates were prepared, sterilized and solidified. After solidification bacterial cultures were swabbed on these plates. Using filter disc immersed in iron nanoparticles solution $(25 \mathrm{mg} / \mathrm{ml})$ and placed in the nutrient agar plate and kept for incubation at $37^{0} \mathrm{C}$ for 48 hours. Zones of inhibition for control. The experiments were (6). 


\section{Antifungal activity}

The fungal suspension of Aspergillus flavus Candida spp was prepared in normal saline by transferring the organism from fresh cultures $\left(1 \times 10^{8}\right.$ cells $\left./ \mathrm{ml}\right)$. To determine the antifungal cultures were poured with a Sabourauds glucose agar medium $(30 \mathrm{ml})$ in petri plates $(90 \mathrm{~mm})$. Sterilized filter paper discs (Whatman No. 1; $6 \mathrm{~mm}$ in diameter) soaked in $25 \mathrm{mg} / \mathrm{ml}$ concentrations of iron nanoparticle were taken out with sterilized forceps and air-dried and placed on plates with the different organisms. The plates were incubated for 7 days at $25^{\circ} \mathrm{C}$. After incubation, the inoculated plates were observed for inhibition zone(7).

of Mentha pulegium L from pale yellow to black color Figure ( 1). The UV- VS spectrum of Fe3O4-NPs of the Mentha pulegium $L$ extract peaks at 400-475 nm indicate the formation of iron nanoparticles Figure (2).

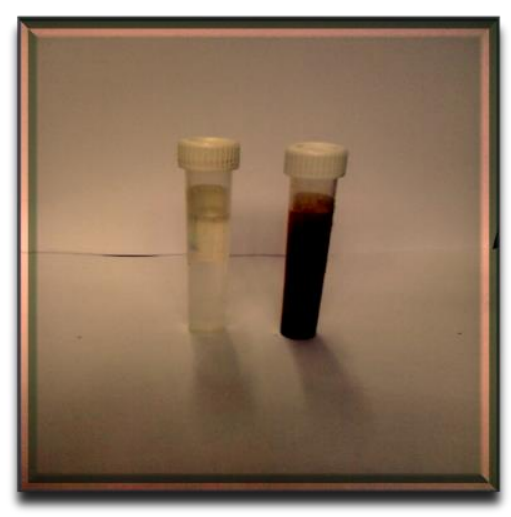

Fig (1) Biosynthesis of nanoparticle

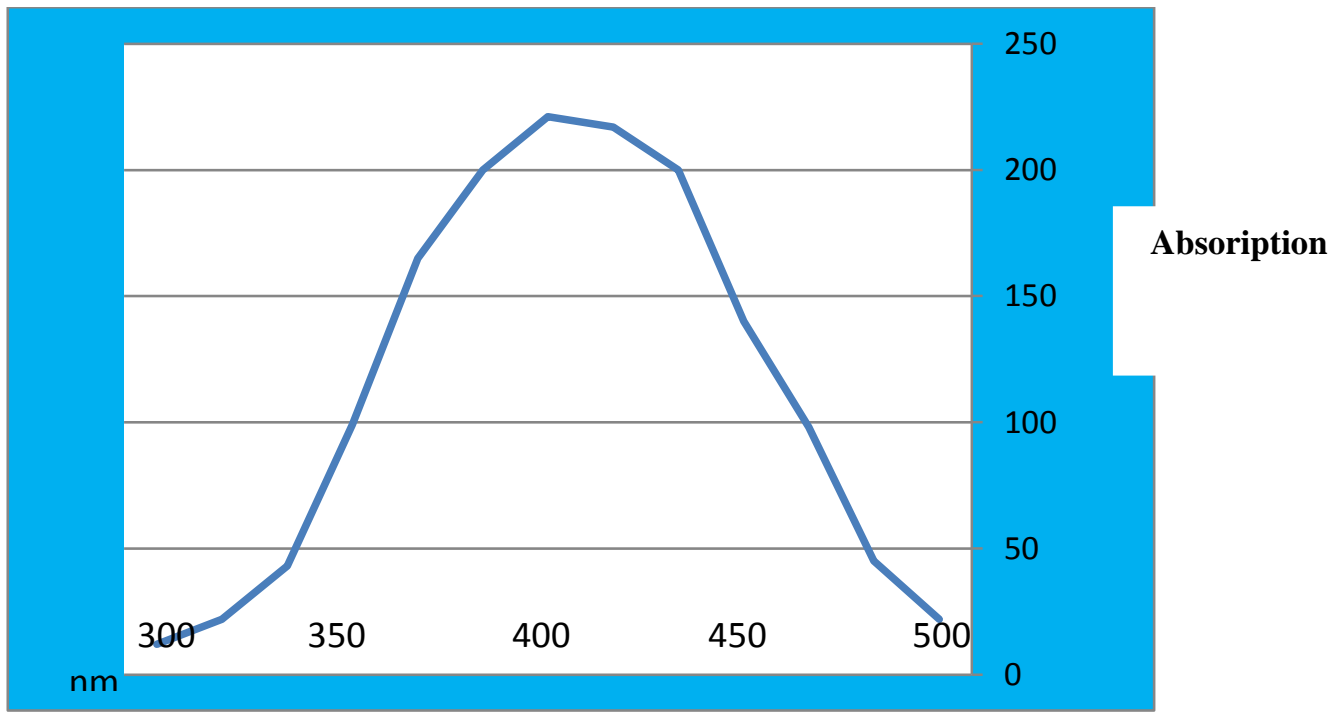

Fig (2) Shows absorbance of samples by different wave length. 


\section{SEM analysis}

The image of SEM for iron nanoparticles were synthesized from Mentha water. It was shown that relatively spherical nanoparticles were formed with diameter of 15 to $25.6 \mathrm{~nm}$. The nanoparticles were not in direct contact even within the aggregates, indicating stabilization of the nanoparticles by a capping agent $(9,10)$ (Fig 3$)$.

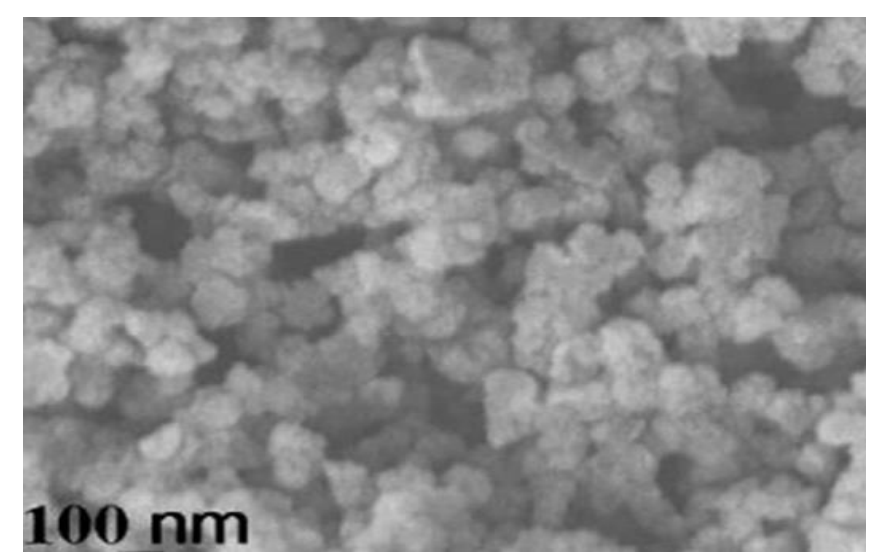

Figure (3) Showed iron nanoparticles by SEM.

Determination the Mentha pulegium L extract functional groups and detection their role in the synthesis of Iron nanoparticles by FTIR analysis bands in different regions of the spectrum for Iron NPs, respectively were analyzed and are shown in Figure(4). The absorption of peak at around 3,394 $\mathrm{cm} 21$ returnes to the $\mathrm{O}-\mathrm{H}$ stretching vibrations of phenols and carboxylic acids. The peak located at around 2,355 cm21 was attributed to the $\mathrm{N}-\mathrm{H}$ stretching or the $\mathrm{C}=\mathrm{O}$ stretching vibrations. The peak located at $1,641 \mathrm{~cm} 21$ could be assigned to the $\mathrm{C}=\mathrm{O}$ stretching in carboxyl or $\mathrm{C}=\mathrm{N}$ bending in theamide group, The peak at 3,388 cm-1 may indicate the involvement of $\mathrm{O}-\mathrm{H}$ functional group in the synthesis of nanoparticles. Peaks (from 1641 to1643 cm-1) indicated carboxyl or amino groups in synthesis nanoparticle. The peak at $771 \mathrm{~cm}-1$ and $760 \mathrm{~cm}-1$ corresponds to $\mathrm{C}-\mathrm{H}$ stretching of aromatic compounds. The formation of $\mathrm{Fe} 3 \mathrm{O} 4$ was characterized by two absorption bands at 535 and $307 \mathrm{~cm}^{-1}$ which correspond to the $\mathrm{Fe}-\mathrm{O}$ bond in magnetite (11) From the FTIR result, the soluble elements present in Mentha pulegium $L \mathrm{~cm}-1$ extract acted as capping agents preventing the aggregation of nanoparticles in solution, and thus playing a relevant role in their extracellular synthesis (12). 


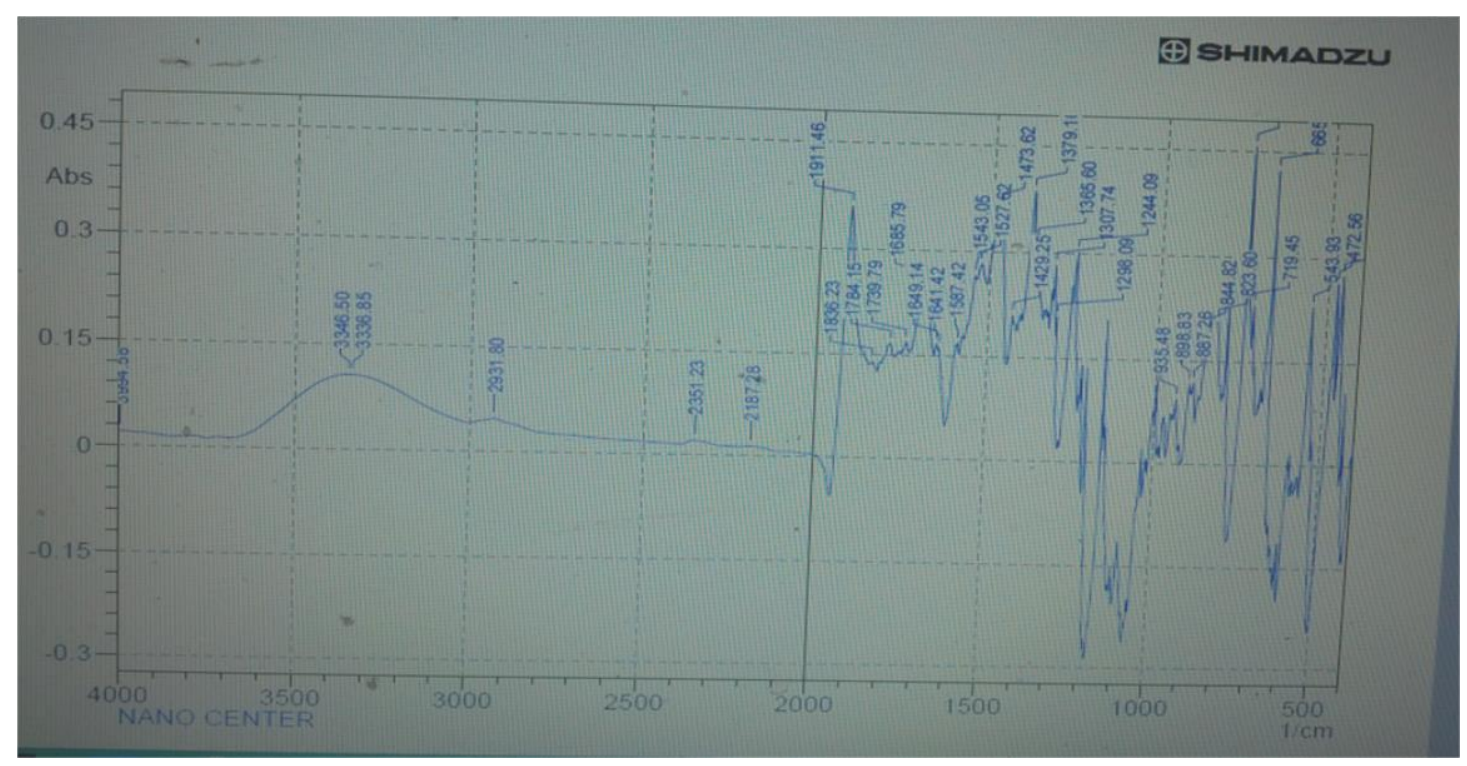

Figure 4. A FT-IR spectrum for the $\mathrm{Fe}_{3} \mathrm{O}_{4}$-NPs.

Using different models for detection antioxidant activity. It was observed that free radicals scavenged by the test compounds in a concentration dependent manner up to the given concentration in all the models. The percentage of scavenging and $\mathrm{IC}_{50}$ values were calculated for all models given in Table (1). The anti oxidative mechanism resulted from metal chelation, free radical scavenging (hydrogen-donatation free radical quenching, or cooperative effects of these properties (12). The ability of nano particles to donate hydrogen was checked by using stable free radical DPPH was formed from the scavenger the reaction is monitered by the decrease of the absorbance at $518 \mathrm{~nm}$ (13).

Table (1) : Comparison of $\mathrm{IC}_{50}$ values of Iron nanoparticle in compartion with standard.

\begin{tabular}{|c|c|c|}
\hline No & Test & $\begin{array}{c}\text { IC50 } \\
\boldsymbol{\mu g} / \mathbf{m l}\end{array}$ \\
\hline 1 & $\begin{array}{c}\text { DPPH radical scavenging } \\
\text { activity }\end{array}$ & 22.5 \\
\hline 2 & $\begin{array}{c}\text { ABTS radical scavenging } \\
\text { activity }\end{array}$ & 33.4 \\
\hline 3 & Iron chelating method & 52.8 \\
\hline
\end{tabular}

\section{Antimicrobial and Antifungi}

Fig. 5. Shows the antimicrobial activity of synthesized Iron nanoparticles against five different bacteria and fungi such as Bacillus subtills, Escherichia coli, Proteus vulgaris and Klebsiella pneumoneae, Candida spp and Aspergillus flavus. As it showed a clear inhibition zone, the synthesized nanoparticles were highly effective in their activity against 
Candida spp and Bacillus subtills folloed by Aspergillus flavus, Eecherichia coli and Klebsiella pneumoneae. The Iron nanoparticles synthesized via green route are highly toxic towards fungal species also when compared to bacterial species. our findings of suggested that the inhibition of oxidation based biological process by penetration of metallic nano sized particles across the microsomal membrane (13),(14).

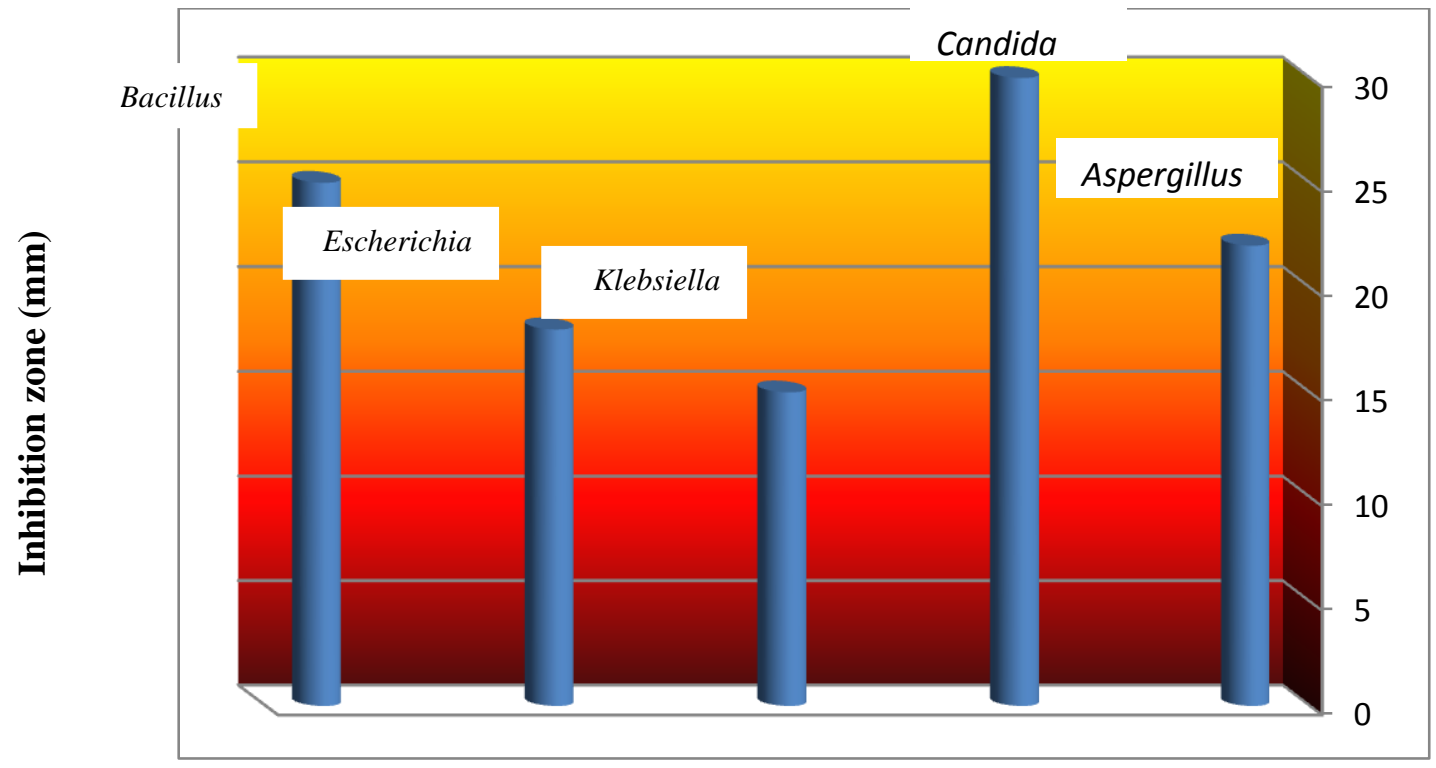

Fig(5) Showed inhibition\% activity of Iron nano particle on microorganism

\section{Inhibition albumin denaturation}

Table (2) showed maximum inhibition of albumin denaturation was $77.5 \%$ observed at $450 \mu \mathrm{g} / \mathrm{ml}$ of nano particle in compared with aspirin at the same concentration. This result investigated that nano particle under study was effective in inhibiting albumin denaturation. Denaturation of proteins refers to cause of inflammation (15). So for this we were studying protein denaturation to evaluate anti-inflammatory activity of iron nanoparticles.

Table (2) showed the results of albumin denaturation Inhibition.

\begin{tabular}{|c|c|c|}
\hline $\begin{array}{c}\text { Concentration } \\
(\mu \mathrm{g} / \mathrm{ml})\end{array}$ & $\begin{array}{c}\text { Absorbance } \\
(\mathrm{nm})\end{array}$ & $\begin{array}{c}\text { inhibition\% } \\
\text { of hemolysis }\end{array}$ \\
\hline$\underline{\text { CONTROL }}$ & $\underline{0.57 \pm 0.01}$ & $=$ \\
\hline$\underline{150}$ & $\underline{0.32 \pm 0.014}$ & $\underline{37}$ \\
\hline$\underline{250}$ & $\underline{0.29 \pm 0.04}$ & $\underline{59.6}$ \\
\hline$\underline{350}$ & $\underline{0.15 \pm 0.02}$ & $\underline{67.8}$ \\
\hline$\underline{450}$ & $\underline{0.09 \pm 0.07}$ & $\underline{77.5}$ \\
\hline$\underline{450}$ & $\underline{0.15 \pm 0.01}$ & $\underline{81.7}$ \\
\hline$\underline{\text { ASPIRIN }}$ & & \\
\hline
\end{tabular}




\section{Haemolysis Heat Induced Haemolysis}

Table (3) showed the results activity of inhibiting haemolysis at different concentrations of iron nanoparticles. The effective concentration was $300 \mu \mathrm{g} / \mathrm{ml}$ in compare with standard drug Declofenac $400 \mu \mathrm{g} / \mathrm{ml}$ gave agood protection against damaging effect of heat solution.

Table (3) Showed the inhibition of protein denaturation.

\begin{tabular}{|c|c|c|}
\hline Concentration $(\mu \mathrm{g} / \mathrm{ml})$ & $\begin{array}{c}\text { Absorbance } \\
(\mathrm{nm})\end{array}$ & $\begin{array}{c}\text { inhibition\% } \\
\text { of hemolysis }\end{array}$ \\
\hline$\underline{\text { CONTROL- }}$ & $\underline{0.52 \pm 0.01}$ & $=$ \\
\hline$\underline{100}$ & $\underline{0.34 \pm 0.03}$ & $\underline{30}$ \\
\hline$\underline{200}$ & $\underline{0.22 \pm 0.03}$ & $\underline{40.2}$ \\
\hline$\underline{300}$ & $\underline{0.10 \pm 0,04}$ & $\underline{65.6}$ \\
\hline$\underline{400}$ & $\underline{0.15 \pm 0.03}$ & $\underline{80.6}$ \\
\hline \begin{tabular}{|c|c|}
\hline$\underline{400}$ \\
Declofenac
\end{tabular} & $\underline{0.13 \pm 0.07}$ & $\underline{85}$ \\
\hline
\end{tabular}

\section{Refernces:}

1. McKay DL, Blumberg JB (2006). A review of the bioactivity and potential health benefits of peppermint tea (Menthapiperita L.). Phytother Res 20:619-6332.

2.Yadegarinia D, Gachkar L, Rezaei MB, Taghizadeh M, Astaneh SA. (2006). Biochemical activities of Iranian Mentha piperita L. and Myrtus communis L. essential oils. Phytochemistry 67:1249-1255

3. Mimica-Dukić N, Bozin B, Soković M, Mihajlović B, Matavulj M. (2003). Antimicrobial and antioxidant activities of three Mentha species essential oils. Planta Med 69:413-419. 4. Bai H, Liu X. (2010). Green hydrothermal synthesis and photoluminescence property of $\mathrm{ZnO} 2$ nanoparticles. Mater. Lett. 64: 341.

5.Mahdavi, M.; Ahmad, M.B.; Haron, M.J.; Gharayebi, Y.; Shameli, K.; Nadi, B. (2013). Fabrication and characterization of $\mathrm{SiO} 2 /(3$-aminopropyl) triethoxysilane-coated magnetite nanoparticles for lead(II) removal from aqueous solution. J. Inorg. Organomet. Polym. Mater., 23, 599-607.

6. Cruickshank R. (1968). Medical microbiology: a guide to diagnosis and control of infection. Edinburghand London: E\&S. Livingston Ltd. 11th (ed, p.88.

7- Shankar S.S, Rai A, Ahmad A, Sastry M.J.( 2004). Rapid synthesis of Au, Ag and bimetallic Au shell nanoparticles using Neem. J. Collid.Interface. Sci, , 275: 496-502.

8-Shankar,S.S., Ahmed, A. B. Akkamwa,B. Sastry, A. Rai and Singh. A. (2004). Biological synthesis of triangular gold nanoprism. Nature 3: 482.

9- Song, J.Y. and B. S. Kim.(2008). Biological synthesis of bimetallic Au/Ag using persimmon (Diopyros kaki) Leaf extract. Korean. J. chem. Eng., 25(4): 808. 
10- Gardea-Torresdey J.L, Gomez E, Peralta- Videa J, Parsons J.G, (2003). Troiani H.E, Jose-Yacaman., Synthesis of gold nanotriangles and silver nanoparticles using Aloe vera plant extract. Langmuir, 13: 1357.

11- Mishra Y.K, Mohapatra S, Kabiraj D, Mohanta B, Lalla N.P, Pivin J.C, AvasthiD.K.,(2007). Synthesis and characterization of Ag nanoparticles in silica matrix by atom beam Sputtering. Scr. Mater, 56, 629-632.

12- Singh, M.; Kalaivani, R.; Manikandan, S.; Sangeetha, N. (2013) Kumaraguru, A.K. Facile green synthesis ofvariable metallic gold nanoparticle using Padina gymnospora, a brown marine macroalga. Appl. Nanosci., 3:145-151.

13- Dehpour, A.A. Ebrahimzadeh, M.A. Nabavi, S.F., Nabavi, S.M. (2009). Antioxidant activity of methanol extract of Ferula assafoetida and its essential oil composition, Grasas Aceites, 4: 405-412.

14- Murugasan N, Vember S, Damodharan C. (1981). Studies on erythrocyte membrane IV: In Vitro hemolytic activityof oleander extract. Toxicol Lett., 8: 33-38.

15- Opie E L. (1962 ). On the relation of necrosis and inflammation to denaturation of proteins. J.Exp. Med., 115: 597-608. 